\title{
Analysis of stress and academic-sports commitment through Self-organizing Artificial Neural Networks Análisis del estrés y el compromiso académico-deportivo mediante Redes Neuronales Artificiales Auto-organizativas \\ *Helio Carratalá Bellod, *Vicente Buendía Ramón, **Eduardo Carballeira Fernández, *José Francisco Guzmán Luján \\ *U niversidad deValencia (España), **U niversidad deA Coruña (España)
}

\begin{abstract}
The objective of this research was to understand the relationships between the variables resilience, coping, commitment and stress in the academic and sports fields, and their differences based on varied personal typologies. $M$ aterial and M ethods: A selective research methodology was used, with a retrospective ex-post-facto design. The sample was made up of 190 men between the ages of 13 and 17, athletes and students of Compulsory Secondary Education (ESO), Baccal aureate and M iddle GradeVocational Training Results: The artificial intelligence technique SO M, allowed to identify in an autonomous way three clusters of athletes with psychological and sociodemographic characteristics similar to each other and different from those of the rest. Task coping was positively related to resilience and commitment and negatively to stress whereas emotion-oriented coping was positively related to stress. Conclusions: Athlete students tend to use the same coping strategies when facing stressful situations that they use in their sports practice. The levels in the variables analysed depend on the type of student and athlete, which can be used to identify risk groups and carry out interventions for their improvement.

Keywords: Sports Psychology, Education, Coping, Resilience, Adolescence.

Resumen. 0 bjetivo: El objetivo de estainvestigación fue conocer las relaciones entre las variables resiliencia, afrontamiento, compromiso y estrés en el ámbito académico y deportivo, y sus diferencias en función de diferentes tipologías personales. Material y M étodos: Se empleó una metodología de investigación selectiva, con un diseño ex-post-facto retrospectivo. La muestra estuvo formada por 190 varones de edades comprendidas entre los 13 y los 17 años, deportistas y estudiantes de Educación Secundaria $O$ bligatoria (ESO ), Bachillerato y Formación Profesional de Grado M edio. Resultados: La técnica de inteligencia artificial SOM, permitió identificar de un modo autónomo tres clústeres de deportistas con características psicológicas y sociodemográficas semejantes entre sí y distintasalos del resto. El afrontamiento detarease relacionó positivamente con la resiliencia y el compromiso y negativamente con el estrés y el afrontamiento centrado en la emoción se relacionó positivamente con el estrés. Conclusiones: Los estudiantes deportistas tienden a emplear en el entorno académico las mismas estrategias de afrontamiento ante situaciones de estrés que usan en su práctica deportiva. Losniveles en las variables anal izadas dependen de latipologíade estudiantey deportista, lo cual puede servir paraidentificar grupos de riesgo y realizar intervenciones parasu mejora.
\end{abstract}

Palabras Clave: psicología deportiva, educación, afrontamiento, resiliencia, adolescencia.

\section{Introduction}

The results of the latest survey carried out by the Ministry of Education, Cultureand Professional Training (MECFP, 2020), in relation to the current state of education in Spain, reflects worrying data regarding the academic dropout of the pre-university adolescent population. It shows an average dropout rate in 2019 of $17.2 \%$, the case of men presents a special concern, with $21.4 \%$ compared to $13.0 \%$ for women. Although it is true that in recent years there has been a trend towards

Fecha recepción: 04-01-21. Fecha de aceptación: 11-03-21

Helio Carratalá Bellod

helio.carratala@uv.es a reduction in early school leaving, it is still higher in men. In 2019 Spain, it is at the head of the entire European Union (EU), almost doubling its average (11.9\%) (INE, 2020).

Regarding the sports habits of the population over 15 years of age, the sports statistics yearbook (MECFP, 2020) shows a low participation in weekly sports practices (46.2\%), these values being lower than the European average (54.0\%). This same document shows that age, sex and studies are determining variables. By sex, anotable difference is observed, with men practicing sports 8.3 points higher than that of women. If we look at the level of studies data related to Compulsory Secondary Education (ESO), Baccalaureate and Middle Level Professional Training (FPGM), in which the scope of this research is focused, weekly sports practice is 
reduced to $39.4 \%$. Sports practice is associated with a series of benefits related to psychophysical health. Among the psychological benefits, which are the object of study of the research, multiple studies highlight its usefulness in order to reduce anxiety and stress, and also to increase self-esteem, discipline or resilience (Jiménez et al., 2008; Serrano et al., 2015).

The studies that have analysed the association between academic performance and sports practice (CDE, 2005; Maureira, 2018) have shown that as the academic level increases, sports practice increases, this being $64.1 \%$ in the population with higher education or equivalent and $39.4 \%$ in those with basic primary or secondary studies (MECFP, 2020). This fact justifies the need to delve into the variables that determine sports and academic dropout.

Some of the factors common to academic and sports performance are certain types of coping strategies associated in a positive or negative way with resilience, commitment or stress (Flores et al., 2017; O liveira et al., 2016). There is no firm consensus on the term resilience (López-Suarez, 2014) since it is a changing concept throughout the life of the subject. N evertheless, there is an agreement to understand it as a positive and effective aspect in adverse situations (Luthar \& Cichetti, 2000). 0 ne of the most accepted definitions is found in Luthar et al. (2000) who understands resilience as the dynamic process of positive adaptation to a context of adversity, improving their commitment towards both academic and sports practice. Studies about this varia ble in any sports context are scarce (Serrano-N ortes et al. , 2021). We understand commitment as the level of adherence to the practice of a certain activity. $0 n$ the other hand, we under stand stress as the set of alterations in the normal functioning of the person in the presence of a certain stimulus (Sandín, 1995). Stress and anxiety are the ones that, when they become chronic, can lead to burnout syndrome, resulting in abandonment of the activity as proposed in the Stress Process M odel (SPM) updated by Tobon et al. (2004). In turn, this same theoretical model shows the importance of sociodemographic variables associated with the perception of stress.

For the analysis of the relationship between the psychological and sociodemographic variables with the variables related to stress and anxiety, in this study a type of Artificial Intelligence (AI) called Self-organizing Artificial Neural Networks (ANN-SO M) was used, which simulate the functioning of the brain and the nervous system and are especially indicated for the treatment of large volumes of data(Serrien et al., 2017). SO M networks perform Visual Data Analysis (VDA), by means of a non-linear regression algorithm named Expectation Maximization, to graphically reflect the relationships between data without using human intervention in this process. These networks are especially indicated for the visualization, clustering and abstraction of data (Kohonen et al., 2001) given their ability to graphically present information in an orderly way (Haroz \& W hitney, 2012; Hofmann et al., 2012) following this pattern, they have a suitability for use in the field of education (Thuneberg \& H otulainen, 2006) given their capacity for grouping and identifying groups. They are also suitable for use in sports due to their ability to predict results (Schöllhorn et al., 2014; Sun et al., 2016).

The aim of study of this research was to analyse how the stress variables indicated in the SPM (resilience, coping and stress) are related to the academic and sports commitment of young athletes. Following the model proposed by Fletcher et al. (2006), they hypothesized that the perception of stress would be positively related to emotion-oriented coping and negatively to taskoriented activities, resilience, and commitment. It was also hypothesized that the stress variables in the sports environment would be related to the same variables applied to the academic environment. Finally, we hypothesize that ANN-SOM would allow the identification of groups with psychological and sociodemographic characteristics that are very similar to each other and different from the rest of the groups, in order to study the intrinsic characteristics of each group (Serrien et al., 2017).

\section{Material and method}

A selective research methodology was used, with a retrospective ex-post-facto design. This methodology is characterized by a direct collection of data thanks to the participation of the person. This is possible due to the use of standardized instruments, the selection of variables, and the researcher's intention to know the possible relationship among covariations (Anguera, 2003).

\section{Participants}

The sample was made up of 190 men aged between 13.58 and 16.64 years, with an average age of 14.87 years, and with an average academic mark of the previous year of 6.98 out of 10 . The inclusion criteria in 
the study were as follows: male, secondary education student, sports-practicing per son and dweller, at the time of study, in theValencian Community.

\section{Measurements}

Data collection for subsequent analysis was carried out using a battery of tests, all of them validated for the Spanish population. W ith this battery it was intended to obtain scores on resilience, coping, commitment and stress in academic and sports environments. Sports resilience was measured with the Wagnild and Young 14-item Sports Resilience Q uestionnaire (RS-14), validated by Sánchez-Teruel and Robles-Bello (2015). Academic resilience was measured with the Connor and Davidson CD-RISC questionnaire validated by Serrano-Parra et al. (2012). Sports coping was measured by validation of M olinero et al. (2010) Coping Strategies Q uestionnaire in Sports Competition. The analysis of the Academic Coping Strategies was measured using the Sandin and Clorot (2003). Sports commitment was measured with the Orlick Sports Commitment Scale validated by Belando (2012). Academic commitment was measured using the Schaufeli and Bakker UW ES-S Q uestionnaire, validated and shortened (9-item) by Parra and Pérez in 2012. Sports stress was measured using the EEAD Q uestionnaire by Pedrosa et al. (2012). To analyze academic stress, it was employed the Cohen et al. Perception Scale (EEP / PSS) in its 14 items validated by Remor and Carrobles (2001). All of our questionnaires presented an appropriate reliability. The analysis of reliability and dimensions is shown in table 1. The responses were presented by means of a Likert scale with a range of values from 1 (never) to 5 (very often) in all variables except for the one regarding academic commitment, which uses a Likert scale with values from 0 (never) to 6 (every day).

The dataw as collected in the participant's educational or sports centers, always keeping into account the presence of their coach/ teacher and a member of the researching team in case there was any doubt. Previously, they were provided with a document indicating the procedure. The athletes were contacted through their high school and/ or sportscentersthroughout the season. Anonymity was ensured by providing two encrypted documents to the participants. W ith one of them, the study participants were informed about the purpose of the study, their granted rights as study participants, as well as their informed consent. The sociodemographic data and the tests were exclusively detailed on the other document, with no relation whatsoever between them.

\begin{tabular}{|c|c|c|c|}
\hline Variable & Q uestionnaire & Items $\quad$ Measures & $\mathrm{a}$ \\
\hline Sport Coping & $\begin{array}{l}\text { Coping Strategies in Sport Competition } \\
\text { (M olinero et al., 2010) }\end{array}$ & $\begin{array}{l}\text { Task Coping } \\
38 \text { Emotional Coping } \\
\text { Distance Coping }\end{array}$ & $\begin{array}{l}.859 \\
.738 \\
.658\end{array}$ \\
\hline Academic Coping & $\begin{array}{l}\text { Coping Stress Q uestionnaire (Sandín \& } \\
\text { Chorot, 2003) }\end{array}$ & $\begin{array}{l}\text { Task Coping } \\
42 \text { Emotional Coping } \\
\text { Distance Coping } \\
\end{array}$ & $\begin{array}{l}.742 \\
.805 \\
.601 \\
\end{array}$ \\
\hline Sport Resilience & $\begin{array}{l}\text { 14-Items Sports Resiliencie } \\
\text { Q uestionnaire (RS-14) (Sanchez-Teruel } \\
\text { \& Robles-Bello, 2015) }\end{array}$ & 14 Sport Resilience & .827 \\
\hline Academic Resilience & CD-RISC (Serrano- Parra et al., 2012) & 17 Academic Resilience & .874 \\
\hline Sport Stress & $\begin{array}{l}\text { EEAD Q uestionnaire (Stress Scale in the } \\
\text { Sports Field) (Pedrosa et al., 2012) }\end{array}$ & 15 Sport Stress & .834 \\
\hline A cademic Stress & $\begin{array}{l}\text { Stress Perception Scale (EEP/ PSS) } \\
\text { (Remor \& Car robles, 2001) }\end{array}$ & 14 Academic Stress & .757 \\
\hline Sport Commitment & $\begin{array}{l}\text { Sports Engagement Scale (Belando et } \\
\text { al.,2012) }\end{array}$ & 11 Sport Commitment & .901 \\
\hline & $\begin{array}{l}\text { Q uestionnaire UWES-S (Parra \& Pérez, } \\
\text { 2010) }\end{array}$ & $9 \begin{array}{l}\text { Academic } \\
\text { Commitment }\end{array}$ & .899 \\
\hline
\end{tabular}

A sociodemographic data questionnaire was also administered where they were asked the place of residence, aspects related to their sports practice, such as what sport they practiced, whether they were competitors or not, the years of sports practice, the reasons for practicing (competing, having fun, be healthy), and the sports level.

Regarding their academic level, they were asked about the average of the academic qual ifications of the previous year, type of educational centre in which they studied (public, public-funded or private), if they had repeated any academic year, the preferences of the educational area (arts/ human studies or sciences) and practice of a regulated extracurricular study (music, foreign languages or others).

\section{Procedure}

After approval by the Human Research Ethics Committee of the U niversity of Valencia (procedure number H1521722527067), the scales and informed consent were administered by the study researchers to proceed to the application of the questionnaires by the athletes/ students. Subsequently, the datawere processed using AN N-SO M and the differences between clusters were analysed. The discussion and conclusions were elaborated when the results were obtained.

\section{Data Analysis}

Data analysis was performed using an unsupervised self-organizing ANN (SOM). The SOM algorithm is based on an ordered grid of elements with the same dimensions as the data to be processed. These elements or neurons gradually adapt the information they contain to the conforming input data. It can be described as a non-linear, ordered and smooth mapping of the input data sets, on the elements of a low-dimensional array. This mapping has similarities with classical vector quantification, obtaining asummary of the data(M akhoul 
et al., 1985). Due to its ability to provide a topological projection of high-dimensional data, the SO M al gorithm can be considered as a regression process in which only one set of input data is considered in each step of the process. A repetitive process is followed with each element of the sample that participates in the training that gradually adapts the network in such a way that the values contained in its neurons summarize the input sample. Although, unlike traditional vector quantification, in this case the mapping is ordered, a visualization of the original distribution is, therefore, achieved.

The training process is configured by various parameters, among which a couple of them stand out: the learning parameter á ( $\mathrm{t}$ ) that quantifies the response sensitivity of neurons to each element of the input sample and the neighbouring parameter ó (t) which explains how each element of the sample affects the set of neurons.

The parameters for the training of the SO M have been chosen by means of a genetic algorithm that is exposed below: 50,000 networks are trained, of which the 50 «survivors» with the best quality are chosen. These parameters recombine and undergo mutations, building a new generation of trainings from these combinations and modifications. The process is repeated successively, until the quality indicator converges. The quality indicator used, based on the study by Kaski and Lagus (1996), includes criteria to take into account the quantification error, the level of approximation of the neuron values to the input data, the topographic error, and the possibility of viewing the data in the resulting SOM.

Subsequently, the neurons were grouped in clusters using the algorithm called expectation-maximization from Dempster et al. (1977), selected for its independence from the spatial distribution of the elements. In this way, the athletes in the study can be organized into three large groups or clusters.

The introduction of the data to the $\mathrm{SO} \mathrm{M}$ was carried out with the free program www.livingforsom.com adapted to carry out automatic calibration of the training parameters of the networks using genetic al gorithms.

Finally, onceall the clusterswere obtained, they were analysed; taking into account the differences between them in the psychological and sociodemographic varia bles.

In order to interpret the results, it is convenient to make a brief explanation of the SO M reading. The colours that appear in each of the layers reflect the areas with common values. In this case, the blue values indicate low values and the red ones represent high values; the darker they are shown, the higher the values obtained and inversely, the lighter the lower. This reading is comparable to data from weather maps that appear on television. W hen we select a cell, colour zone or cluster, the program's viewer automatically selects the same for each layer. N ext, we must observe the colour bar located at the bottom of each layer-window where the average value of the selected area appears in order to be able to understand the grid. Finally, we must go to the HIT layer where the number of subjects is indicated, as well as the percentage of the total sample, which is in the selected area.

\section{Results}

A two-level SOM analysis was performed. A first level of general analysis and a second level of clusters analysis, in which the intrinsic characteristics of each cluster were studied. Likewise, the differences between clusters were analysed using inferential statistics.

\section{General SOM analysis}

The general analysis of the different psychological variables (figure 1) showed the existence of three clusters that showed three typical forms of relationships and level between the scores of the study.

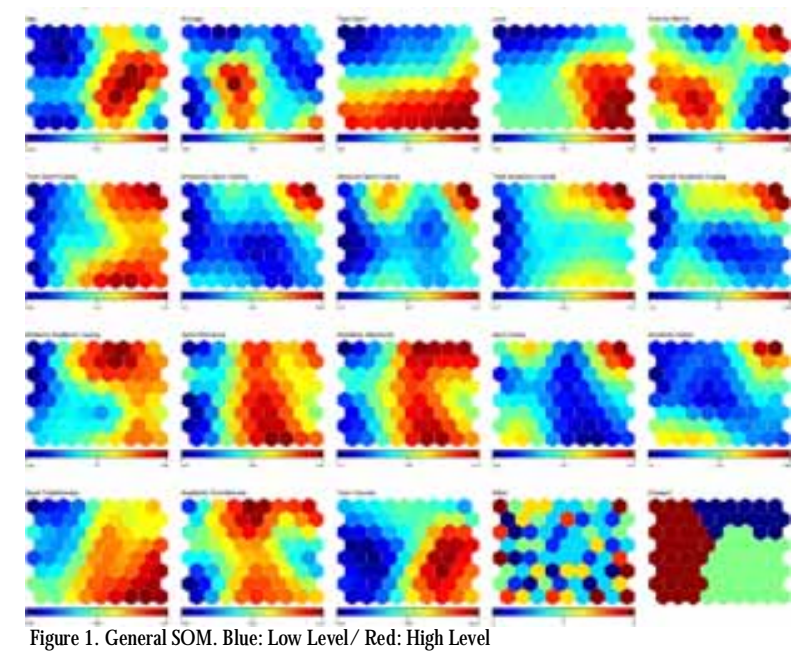

\section{Cluster correlation analysis}

In all clusters there was a positive correlation between the same stress variables in the academic and sports environment. The task coping strategy was positively related to resilience and commitment and negatively to stress. Emotion-oriented coping was positively related to stress and negatively to resilience and commitment. 
Table 2.

Correlation matrix (Spearman) between variables for each cluster

\begin{tabular}{|c|c|c|c|c|c|c|c|c|c|c|c|}
\hline Cluster 1 & 1 & 2 & 3 & 4 & 5 & 6 & 7 & 8 & 9 & 10 & 11 \\
\hline 1.Sport task oriented coping & 1.000 & & & & & & & & & & \\
\hline 2. Sport emotion oriented coping & $0.324^{* *}$ & 1,000 & & & & & & & & & \\
\hline 3. Sport distancing oriented coping & 0.194 & $0.418^{* *}$ & 1.000 & & & & & & & & \\
\hline 4. Sport Resilience & 0.126 & -0.147 & 0.066 & 1.000 & & & & & & & \\
\hline 5. Sport Stress & 0.141 & $0.364^{* *}$ & 0.191 & $-0.380^{* *}$ & 1.000 & & & & & & \\
\hline 6. Sport Commitment & 0.115 & -0.135 & -0.134 & $0.276^{*}$ & -0.106 & 1.000 & & & & & \\
\hline 7. Academic task oriented coping & $0.465^{* *}$ & $0.295^{*}$ & $0.349^{* *}$ & 0.105 & 0.044 & -0.123 & 1.000 & & & & \\
\hline 8. Academic emotion oriented coping & $0.278^{*}$ & $0.408^{* *}$ & $0.236^{*}$ & 0.006 & $0.286^{*}$ & -0.065 & $0.258^{*}$ & 1.000 & & & \\
\hline 9. Academic distancing oriented coping & $0.276^{*}$ & 0.203 & $0.405^{* *}$ & 0.011 & 0.156 & 0.068 & $0.303^{* *}$ & $0.296^{*}$ & 1.000 & & \\
\hline 10. Academic Resilience & -0.006 & -0.039 & 0.055 & $0.544^{* *}$ & $-0.369^{* *}$ & 0.152 & -0.018 & 0.045 & 0.024 & 1.000 & \\
\hline 11. Academic Stress & 0.088 & 0.144 & $0.257^{*}$ & -0.025 & 0.112 & 0.202 & 0.079 & 0.007 & $0.276^{*}$ & -0.094 & 1.000 \\
\hline 12. Academic Commitment & 0.130 & $0.235^{*}$ & 0.178 & 0.130 & -0.037 & -0.122 & 0.195 & 0.188 & -0.050 & $0.259^{*}$ & $-0.271^{*}$ \\
\hline Cluster 2 & 1 & 2 & 3 & 4 & 5 & 6 & 7 & 8 & 9 & 10 & 11 \\
\hline 1.Sport task oriented coping & 1.000 & & & & & & & & & & \\
\hline 2. Sport emotion oriented coping & 0.210 & 1.000 & & & & & & & & & \\
\hline 3. Sport distancing oriented coping & $0.364^{*}$ & $0.525 * *$ & 1.000 & & & & & & & & \\
\hline 4. Sport Resilience & 0.194 & -0.199 & 0.139 & 1.000 & & & & & & & \\
\hline 5. Sport Stress & 0.251 & $0.684 * *$ & $0.425 * *$ & -0.311 & 1.000 & & & & & & \\
\hline 6. Sport Commitment & $0.404 *$ & -0.060 & 0.156 & 0.157 & -0.120 & 1.000 & & & & & \\
\hline 7. Academic task oriented coping & $0.394 *$ & 0.232 & 0.141 & 0.053 & $0.358 *$ & 0.183 & 1.000 & & & & \\
\hline 8. Academic emotion oriented coping & 0.161 & 0.304 & 0.128 & 0.019 & 0.219 & 0.052 & $0.487 * *$ & 1.000 & & & \\
\hline 9. A cademic distancing oriented coping & 0.044 & -0.213 & -0.102 & -0.243 & -0.215 & -0.130 & -0.035 & 0.043 & 1.000 & & \\
\hline 10. Academic Resilience & $0.502 * *$ & -0.065 & 0.022 & $0.392^{*}$ & -0.271 & 0.257 & 0.303 & 0.080 & -0.001 & 1.000 & \\
\hline 11. Academic Stress & 0.152 & $0.488 * *$ & $0.371^{*}$ & -0.206 & $0.370^{*}$ & $0.421 * *$ & $0.385^{*}$ & 0.186 & -0.284 & 0.107 & 1.000 \\
\hline 12. Academic Commitment & 0.139 & -0.120 & 0.146 & $0.478^{* *}$ & -0.269 & 0.201 & -0.013 & -0.065 & -0.255 & $0.353 *$ & 0.032 \\
\hline Cluster 3 & 1 & 2 & 3 & 4 & 5 & 6 & 7 & 8 & 9 & 10 & 11 \\
\hline 1.Sport task oriented coping & 1.000 & & & & & & & & & & \\
\hline 2. Sport emotion oriented coping & 0.179 & 1.000 & & & & & & & & & \\
\hline 3. Sport distancing oriented coping & $0.226^{*}$ & 0.186 & 1.000 & & & & & & & & \\
\hline 4. Sport Resilience & $0.229 *$ & $-0.299 * *$ & -0.021 & 1.000 & & & & & & & \\
\hline 5. Sport Stress & -0.116 & 0.221 & -0.052 & $-0.354 * *$ & 1.000 & & & & & & \\
\hline 6. Sport Commitment & $0.267^{*}$ & -0.048 & 0.037 & 0.130 & -0.098 & 1.000 & & & & & \\
\hline 7. Academic task oriented coping & $0.516^{* *}$ & 0.134 & 0.099 & $0.331^{* *}$ & $-0.228 *$ & 0.127 & 1.000 & & & & \\
\hline 8. Academic emotion oriented coping & $0.449 * *$ & $0.276 *$ & -0.020 & 0.059 & 0.025 & -0.013 & $0.275^{*}$ & 1.000 & & & \\
\hline 9. Academic distancing oriented coping & $0.246^{*}$ & 0.156 & 0.083 & 0.019 & -0.028 & 0.111 & 0.110 & 0.138 & 1.000 & & \\
\hline 10. Academic Resilience & 0.116 & -0.199 & -0.103 & $0.426 * *$ & $-0.294 * *$ & 0.071 & $0.381 * *$ & 0.084 & -0.186 & 1.000 & \\
\hline 11. Academic Stress & 0.175 & 0.108 & $0.243^{*}$ & -0.171 & $0.278^{*}$ & -0.115 & 0.103 & 0.186 & 0.143 & 0.028 & 1.000 \\
\hline 12. Academic Commitment & 0.158 & -0.143 & 0.042 & $0.303^{* *}$ & $-0.298 * *$ & 0.008 & 0.137 & 0.111 & -0.116 & $0.335 * *$ & -0.058 \\
\hline
\end{tabular}

of the youngest athletes in the sample ( $\mathrm{M}=13.95, \mathrm{SD}=1.50$ ) with motivations aimed mainly to healthy issues followed by reasons for fun. At an academic level, itscomponentspresented the lowest levels of taskoriented coping and distancing, stress (along with group 3), resilience and commitment, thus showing less ability to successfully cope with this context, although it does not imply a big problem. We can say that they were disconnected from the academic environment and therefore could be a group at risk of academic abandonment. They present a lower level of sports performance than group 3 and lower coping focused on the
By clusters, in cluster 1 there was a strong correlation between all coping strategies and resilience in the sports and academic environment, but not between stress and commitment. In cluster 2, a strong correlation was verified between task coping strategies, resilience and stress in the sports and academic environment. Finally, in cluster 3, there was a strong correlation between task and emotion coping strategies, resilience and stress in the academic environment.

\section{Inferential and SOM analysis by clusters}

The application independently generated three clusters, whose mean values in each of the variables can be seen in Table 3. Likewise, an analysis was carried out to study the differences between the scores, set to the characteristics of adjustment to normality and homogeneity of variances. In the case of a good fit, intersubject GLM tests were performed, in the case of lack of fit, Kruskal Wallis tests for multiple comparison and Mann-W hitney $U$ tests for pairwise comparisons were performed. The multiple comparison tests showed significant differences in all the variables except in the academic record. From the pairwise comparisons, we extracted the following characteristics from each of the clusters.

Cluster 1. Athletes with low levels of coping, resilience and academic and sports commitment

Formed by $38.42 \%$ of the sample $(n=73)$, made up task, resilience and commitment than the other clusters and showed an intermediate stress level, below cluster 2.

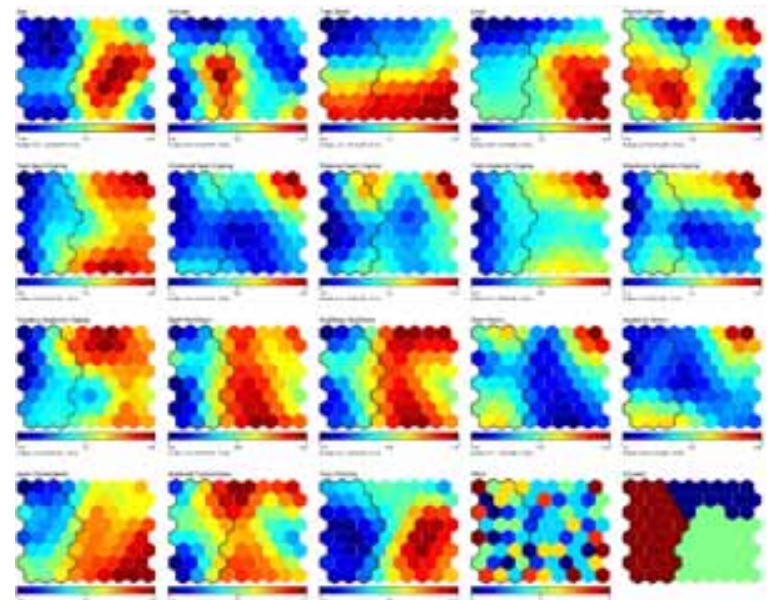

Figure 2. Cluster 1. The highlighted area indicates the cluster distribution/ Blue: Low Level/ Red: High Level

Cluster 2. Athletes with high levels of resilience and commitment in the academic field

This cluster consisted of $20.53 \%$ of the sample ( $n=$ 39 ), with an average age of 14.97 (DT $=1.98$ ) years. Together with group 1 they had a lower sports level than group 3.

The athlete students were characterized academically by showing the highest levels of all types of coping, resilience, stress and commitment. It was a group committed to their studies. At the sports level, they also showed high levels of all types of coping, with 
higher levels of resilience and commitment than cluster 1 and the highest stress levels of all clusters. High levels of stress also showed a high correlation with emotion-oriented coping $(r=.684, p<.01)$. The cross relationships between the sports and academic environment were significant. The way of coping with sport was related to the academic environment since task-oriented sports coping had a high correlation with academic resilience $(r=.502, p<.01)$ and sportscoping with emotion had also a strong relationship with academic stress $(r=.488, p<.01)$, so this group would greatly benefit from a program aimed at improving sports coping due to its possible transfer to the academic environment.

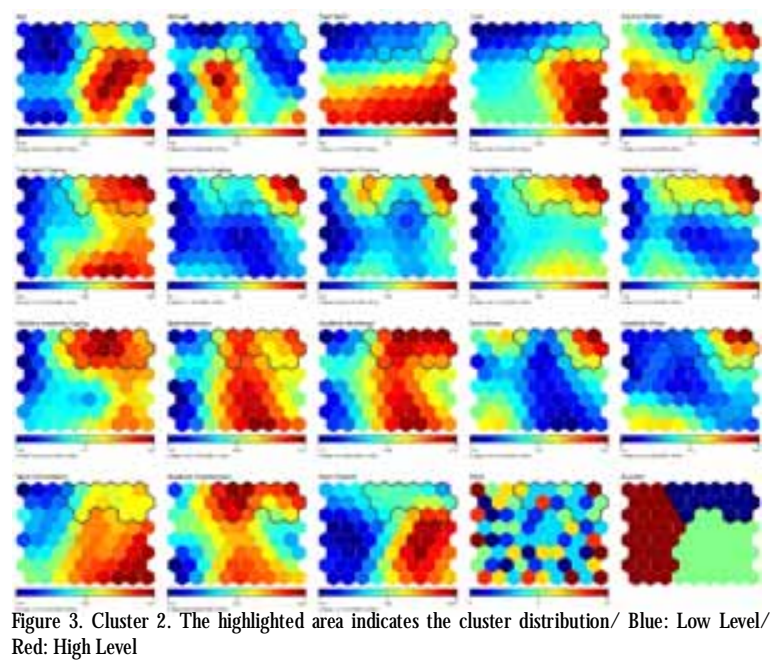

Cluster 3. High-level competitors with high resilience and commitment to sports practice

This cluster was made up of $41.05 \%$ of the sample ( $n=78)$, the group of subjects was older ( $M=15.72$, $S D=1.64$ ) and had a higher competitive level, motivated by the sake of competing and for fun. At the academic level, they presented high levels of taskoriented coping and distancing (higher than cluster 1), and their emotion-oriented coping was low (lower than

Table 3

Resul ts of the analysis of the differences between clusters

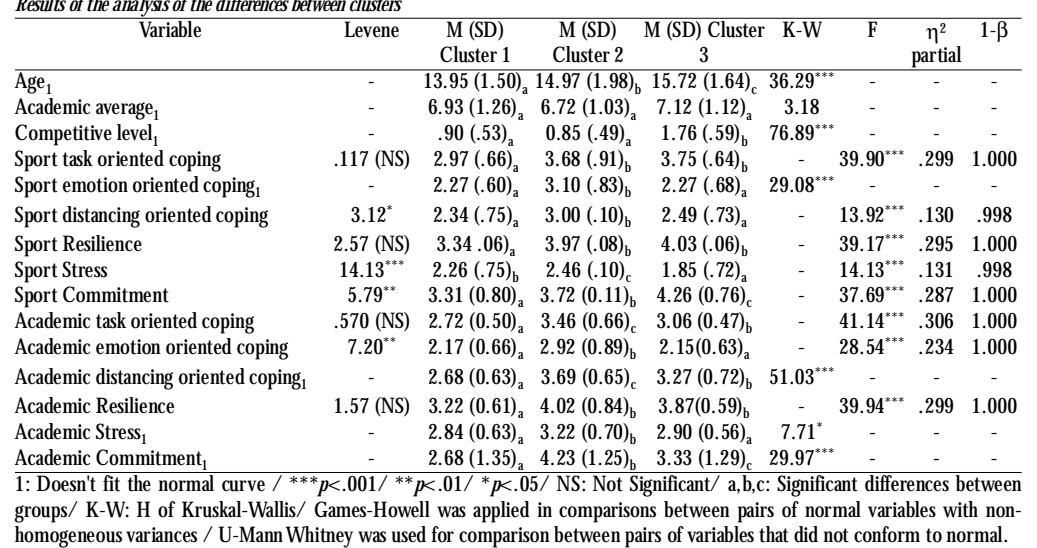
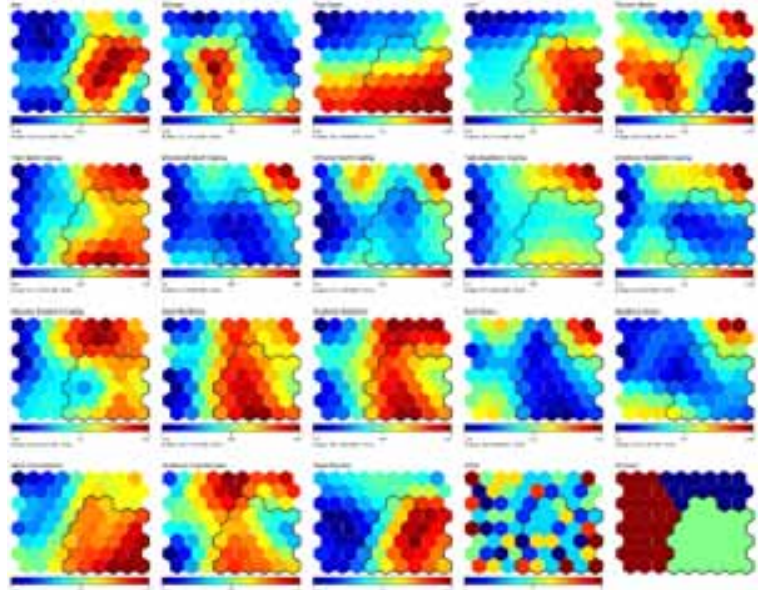

Figure 4. Cluster 3. The highlighted area indicates the cluster distribution/ Blue: Low Level/ Red: High Level

cluster 2). They had low stress levels (similar to group 1) and high levels of resilience (similar to group 2) and commitment (lower than group 2). Regarding the sport performance, they showed high levels of task-oriented coping and low levels of emotions and detachment. Likewise, it was the group with the greatest resilience and commitment and the least stress.

The following is a summary table of the data extracted in the clusters.

\section{Discussion}

The results obtained in the study reveal two key aspects. The first is the suitability of the AN N SO M tool for the creation of student groups in the field of Education and Sport. The second was the verification of the hypothesized relationships between the psychological and sociodemographic variables of stress between the sports and academic environment.

The SO M networks applied to Physical Education and sport allowed the creation of groups of athlete students, eliminating possible biases derived from the researcher himself (Serrano et al., 2009) and identifying groups at risk or prone to the benefit of intervention programs (Hautamäki \& Nurkkala, 2004; Thuneberg \& Hotulainen, 2006). In the present study, the results of the SOM network made it possible to identify three clusterswith very specific characteristics. Cluster 1, formed by athleteswith low task-oriented coping, resilience and commitment in both the sports and academic environments. It could be considered as a group at high 
risk of both academic and sports dropping-out. Cluster 2 , made up of athletes who used all forms of coping in the academic and sports environment, presented high levels of resilience and commitment in both environments, but al so showed high perception of stress, which was strongly related to coping in emotionoriented environments. Thisgroup would be appropriate to apply a coping training program aimed at reducing the focus on emotions and this way helping them to reduce their perception of stress by preventing burnout. Finally, cluster 3 was made up of those athletes with the best coping profile, with high strategies focused on task, resilience and commitment, and lower levels of stress, both in the academic and sports fields. They were the athletes of the highest level and age. Regarding this group, Guillén and Laborde (2014) indicated that competitors, who are often in contact with stressful situations either in competition or during training, developed greater mental strength, understood as an essential element of resilience and coped better with varied stresfful situations. Later, Flores et al. (2017) indicated that stress levels were lower as athletes had more years of competitive experience.

At the sports level, there are studies that have used SO M to project a large amount of data in a simple graphic way and thus make predictions of results and / or group subjects with similar characteristics, and therefore being able to better adapt the training loads (Lamb et al., 2010; Schöllhorn et al., 2014; Serrien et al., 2017; Sun et al., 2016).

The correlation analysis showed that athlete students tended to use the same stress coping strategies in sports and academics. Likewise, task-focused coping was positively related to resilience and commitment, while emotion-focused coping was positively related to stress. These results agree with the SPM proposals (Fletcher et al., 2006).

The use of task-focused coping strategies was positively associated with resilience and commitment, and negatively with stress, in line with other studies carried out in the sports field (Flores et al., 2017; Gutiérrez et al., 1997; Morgan et al., 1987; O liveira et al., 2016). Therefore, its use should be reinforced both in the academic and sports fields.

This research has showed us three large clusters in which the subjects had psychological and sociodemographic characteristics similar to each other and different from the rest of the groups, all without human intervention using an Al system called AN N SO M. However, in order to compare results, there are a series of limitations such as the scarcity of information on the analysis of resilience in the sports context and the lack of studies that have used an analysis using ANN SO M in the adolescent population. In the future it would be interesting to continue studying this relationship between the sports and academic field of different psychological variables, as well as to carry out interventionsin specific groups with atendency to sports I academic abandonment with the idea of implementing coping techniques aimed at the task of improving resilience and reducing emotional coping and anxiety.

\section{Conclusions}

- The SO M networks are an excellent tool for the field of Education and Sciences of Physical Activity and Sports due to their great capacity to analyse large volumes of data and project their results in a simple way, allowing the creation of groups of athlete students.

- Athlete students tend to use the same coping strategies when facing stressful situations that they use in their sports practice. The scientific evidences indicate that sport task-type coping strategies favor the academic field.

- Not all the athletes in the sample behave equally, and the variables don't correlate in the same way, either. Depending on the membership cluster, the use of coping strategiesvaries, observing that higher-level competitors use task-type strategies as their main coping strategies.

-Task coping is positively related to resilience and commitment and negatively to stress while emotionfocused coping is positively related to stress in the analysed clusters.

\section{References}

Anguera, M.T. (2003). La metodología selectiva en la Psicología del Deporte. En A. Hernández Mendo (Coord.), Psicología del Deporte (Vol. 2). Metodología. (pp. 74-96). Buenos Aires, Argentina: Efdeportes

California Department of Education. (2005). A study of the relationship between physical fitness and academic achievement in California using 2004 test results. Retrieved from http:/ / www.cde.ca.gov/ ta/ tg/ pf/ documents/2004pftresults. doc

Belando, N., Ferriz-M orell, R., \& M oreno-M urcia, J.A. (2012). Validación de la escala de grado de compromiso deportivo en el contexto español. European Journal of Human M ovement, 28, 111-124. 
Dempster, A. , Laird, N., \& Rubin, D. (1977). M aximum likelihood from incomplete data viatheEM al gorithm. Journal of the Royal Statistical Society, Series B (M ethodological), 39(1), 1-38.

Fletcher, D., Hanton, S. \& M ellalieu, S. D. (2006). An organizational stress review: Conceptual and theoretical issues in competitive sport. In S. Hanton $\&$ S. D. Mellalieu (Eds.), Literature reviews in sport psychology (pp. 321-373). Hauppauge, NY: N ova

Flores, P.J., Pérez-Ruvalcaba, S.L., Salazar, C.M.; Manzo, E.G., López-Gutiérrez, C.J., Barajas, L.T., \& Medina, E.J. (2017). Fuentes, síntomas y estrategias de afrontamiento al estrés- competitivo en na dadores. Journal of Sport Psychology, 26(2), 199- 208

Guillén, F. \& Laborde, S. (2014). Higher-order structure of mental toughness and the analysis of latent mean differences between athletes from 34 disciplines and nonathletes. Personality and Individual Differences, 60, 30-35. http:/ / dx.doi. org/ 10.1016/ j. paid.2013.11.019

Gutiérrez, M., Estévez, A., García, J. \& Pérez, H. (1997). Ansiedad y rendimiento atlético en condiciones de estrés: Efectos moduladores de la práctica. Revista de Psicología del D eporte, 6(2), 27-46

Haroz, S. \& W hitney, D. (2012). How Capacity Limits of Attention Inuence Information Visualization Eectiveness. IEEE Transactions on Visualization and Computer Graphics, 18(12), 2402-2410. https:/ / doi.org/ 10.1109/ TVCG.2012.233

H autamäki, J. \& Nurkkala,T. (D ecember 2004). Learning to learn assessment data represented in self organizing maps. In Conference presentation presented at the 0 nline Educa Berlin. Available online at: http:/ / www.dipoli.tkk.fi/ europro/ matkat/ oeb2004/ workshops. html

H ofmann, H., Follett, L., Majumder, M., \& Cook, D. (2012). Graphical Tests for Power Comparison of Competing Designs. IEEE Transactions on Visualization and Computer Graphics, 18(12), 2441-2448. doi: 10.1109/ TVCG.2012.230

Instituto Nacional de Estadística (2020). Abandono temprano de la educación- formación. https:/ / www.ine.es/ $S$

satellite?l $=$ es_es $\alpha c=$ ineseccion_c $c$ cid $=1259925480$ $602 \& p=\% 5 c \&$ pagename $=$ productosyservicios \%2fpysajout\&paraml=pysdetalle\&param3=1259924822888 Jiménez, M., Martínez, P., M iró, E., \& Sánchez, A. (2008). Bienestar psicológico y hábitos saludables: ¿Están asociados a la práctica de ejercicio físico? International Journal of Clinical and Health Psychology,
8, 185-202.

Kaski, S. \& Lagus, K. (1996). Comparing Self-O rganizing Maps. In Von der Malsburg, C., Von Seelen, W., Vorbrüggen, J. C., \& Sendho, B (Eds.). Proceedings of ICAN N 96, International Conference on Articial Neural Networks, Lecture N otes in Computer Science, 809-814. doi: 10.1515/ ijcss-2017-0001

Kohonen T., Schroeder, M.R., \& Huang, T.S. (Eds.) (2001). Self- Organizing Maps. New York, USA: editorial Springer-Verlag. ISBN 3-540679-21-9.

Lamb, P., Bartlett, R., \& Robins, A. (2010). Self$O$ rganising Maps: An $O$ bjective $M$ ethod for Clustering Complex Human M ovement. International Journal of Computer Sciencie in Sport, 9(1), 20-29

López-Suarez, M.R. (2014). Relación entre resiliencia y satiffacción con la vida en jóvenes deportistas. (Tesis doctoral). Universidad de Las Palmas de Gran Canarias, España.

Luthar, S.S. \& Ciccheti, D. (2000). The construc of resiliencie: Implications for interventions and social policies. Development and Psychopathology, 12 (4), 85785.

Luthar, S.S.; Cicchetti, D. \& Becker, B. (2000). The construct of resilience. A critical evaluation and guidelines for future work. Child D evelopment, 7(3), 543-562

Makhoul, J., Roucos, S., \& Gish, H. (1985). Vector quantization in speech coding.

Proceedings of the IEEE, (73)11, 1551-1588.

Maureira, F. (2018). Relación entre el ejercicio físico y el rendimiento académico escolar: revisión actualizada de estudios. EmásF. Revista Digital de Educación Física, 9(53), 168-184. Recuperado de http:// emasf. webcindario.com

M inisterio deEducación y Formación Profesional (2020). Las cifras de la educación en España. Estadísticas e indicadores. https:/ / sede. educacion. gob.es/ publiventa/ las-cifras-de-la-educacion-estadisticas-eindicadores-estadisticas-2020/ organizacion-ygestion-educativa/ 23984

M olinero 0., Sal guero A., \& Márquez, S. (2010). Propiedades psicométricas y estructura dimensional de la adaptación española del cuestionario de estrategias de afrontamiento en competición deportiva. Psicothema. 22 (4), 975-982

Morgan, W., Brown D., Raglin, J., 0 'Connor, P., \& Ellickson, K. (1987). Psychological monitoring of overtraining and staleness. British Journal Sports Medicine, 21(3), 107-114.

O liveira, L.P.; Andrade, J.R., Nickenig, J.R., Ferreira, 
L., N orraila, P., \& Lopes-Vieira, J.L. (2016). Motivación autodeterminada y estrategias de afrontamiento en futbolistas: Un estudio con jugadores en diferentes fases de desarrollo deportivo. Journal of Psychology, 25(2), 261-269.

Parra, P. \& Pérez, C. (2010). Propiedades psicométricas de la escala de compromiso académico, UW ES-S (versión abreviada), en estudiantes de psicología. Revista de Educación y Ciencias de la Salud, 7(2), 128133.

Pedrosa, I., Suárez-Álvarez, J., \& García-Cueto, E. (2012). Construcción de unaEscaladeValoración del Estrés en el Ámbito Deportivo (EEAD). Revista Electrónica de M etodología Aplicada, 17(2), 18-31.

Remor, E. A. \& Carrobles, J. A. (2001). Versión española de la Escala de Estrés Percibido (PSS-14): Estudio psicométrico en una muestraVIH + . Ansiedad y Estrés, 7, 195-201.

Sánchez-Teruel, D \& Robles-Bello, M .A. (2015). Escala de Resiliencia 14 ítems (RS-14): Propiedades psicométricas de la versión en español. Revista Iberoamericana de Diagnóstico y Evaluación - eAvaliação Psicológica, 2(40). 103-113.

Sandín, B. (1995). El estrés. Manual de Psicopatología. Madrid: Editorial McGraw-Hill.

Sandín, B. \& Chorot, P. (2003). Cuestionario de Afrontamiento del Estrés (CAE): desarrollo y validación preliminar. Revista de Psicopatología y Psicología Clínica, 8(1), 39-54. doi: 10.5944/ rppc.vol.8. num.1.2003.3941

Schöllhorn, W., Chow. J.Y., Glazier, P., \& Button, C. (2014). Self-organizing maps and cluster analysis in elite and sub-elite athletic performance. Complex systems in sport. 145-159. https:/ / doi.org/ 10.4324/ 9780203134610

Serrano-Nortes, E., Díaz, M., \& Reche García, C. (2021). Resiliencia y optimismo en gimnasia rítmica. Retos, 41, 581-588. https:/ / doi.org/ $10.47197 /$ retos. v0i41.83086

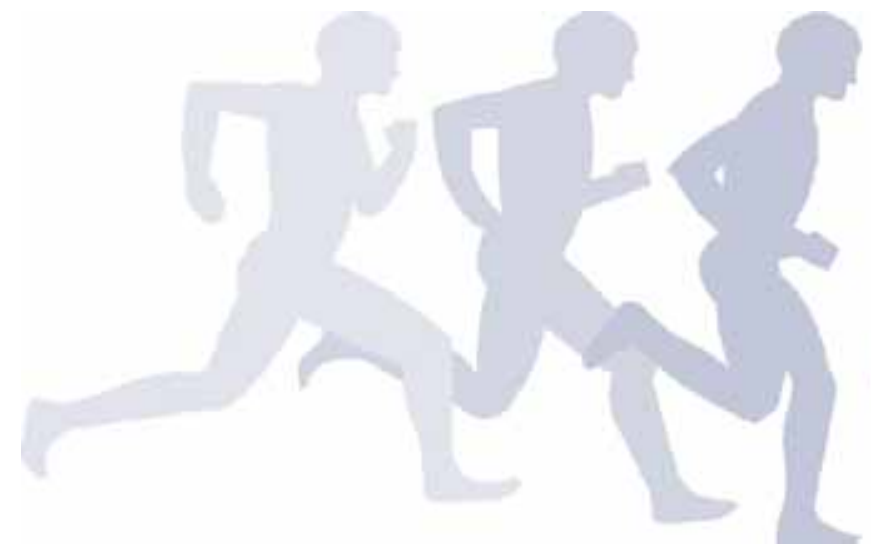

Serrano-Parra, M.D.; Garrido-Abejar, M.; NotarioPacheco, B.; Bartolomé-Gutiérrez, R.; SoleraMartínez, M., \& M artínez-Vizcaíno, V. (2012). Validez de la escala de Resiliencia de Connor-Davidson (CD-RISC) en una población de mayores entre 60 y 75 años. International Journal of Psychological Research, 5(2), 49-57.

Serrano, M.V., López, R. C., Pulido, R. M ., \& Zagalaz, J. C. (2015). Estudio comparativo del rendimiento académico y la actividad física en dos institutos de enseñanza secundariadeAndalucía(España). SporTK: Revista Euroamericana de Ciencias del D eporte, 4(2), 1118.

Serrano, A., Soria, E., \& Martín, J.D. (2009). Redes N euronalesArtificiales. EscuelaT écnica Superior de Ingeniería. Departamento Ingeniería Electrónica. Universidad Valencia.

Serrien, B., Goossens, M. , \& Baeyens, J. P. (2017). Issues in U sing Self-O rganizing M aps in H uman M ovement and Sport Science. International Journal of Computer Sciencein Sport, 16(1), 1-17. doi: 10.1515/ ijcss-20170001

Sun, Q., Liu, H. , Liu, M., \& Zhang, T. (2016). Human activity prediction by mapping groupletsto recurrent Self-O rganizing Map. N eurocomputing 177. 427-440. doi: https: / / doi .org / 10.1016 / jneucom.2015 .11.061.

Thuneberg, H. \& Hotulainen, R. (2006). Contributions of data mining for psychoeducational research: what self-organizing maps tell us about the well-being of gifted learners? High Ability Studies, 17(1), 87-100. doi:10.1080/ 13598130600947150.

Tobón, S., Vinaccia, S., \& Sandín, B. (2004). Modelo procesual del estrés en la dispepsia funcional: implicaciones para la evaluación y el tratamiento. Revista de Psicopatología y Psicología Clínica. Asociación Española de Psicología Clínica y Psicopatología (AEPCP). 9(2), 81-96. doi: https:/ / doi.org/ 10.5944/ rppc.vol.9. num. 2.2004.3977

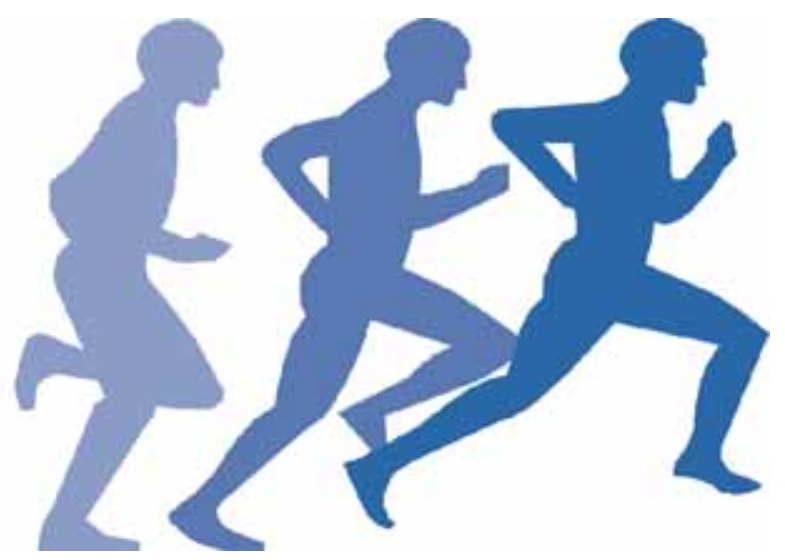

